\title{
Synthetic Analogue of the Natural Product Piperlongumine as a Potent Inhibitor of Breast Cancer Cell Line Migration
}

\author{
Marilia Valli, ${ }^{a}$ Wanessa Altei, ${ }^{b}$ Ricardo N. dos Santos, ${ }^{b}$ Emilio C. de Lucca Jr., ${ }^{c}$ Marco A. \\ Dessoy, ${ }^{c}$ Renan M. Pioli, ${ }^{a}$ Fernando Cotinguiba, ${ }^{d}$ Xavier Cachet, ${ }^{e}$ Sylvie Michel, ${ }^{e}$ Maysa \\ Furlan, ${ }^{a}$ Luiz C. Dias, ${ }^{c}$ Adriano D. Andricopulo ${ }^{b}$ and Vanderlan S. Bolzani ${ }^{*}, a$
}

${ }^{a}$ Núcleo de Bioensaios, Biossíntese e Ecofisiologia de Produtos Naturais (NuBBE), Departamento de Química Orgânica, Instituto de Química, Universidade Estadual Paulista (UNESP), 14800-060 Araraquara-SP, Brazil

${ }^{b}$ Laboratório de Química Medicinal e Computacional, Centro de Pesquisa e Inovação em Biodiversidade e Fármacos, Instituto de Física de São Carlos, Universidade de São Paulo (USP), 13563-120 São Carlos-SP, Brazil

\author{
'Laboratório de Química Orgânica Sintética, Instituto de Química, Universidade Estadual de \\ Campinas (UNICAMP), 13083-970 Campinas-SP, Brazil \\ ${ }^{d}$ Instituto de Pesquisas de Produtos Naturais (IPPN), Centro de Ciências da Saúde, Universidade \\ Federal do Rio de Janeiro (UFRJ), 21941-902 Rio de Janeiro-RJ, Brazil \\ ${ }^{e}$ Laboratoire de Pharmacognosie, UMR 8638 COMETE CNRS, Faculté de Pharmacie de Paris, \\ Université Paris Descartes, Sorbonne Paris Cité, Paris, France
}

\begin{abstract}
Piperlongumine is a natural amide alkaloid isolated from several species of Piper and is described in the literature as selectively cytotoxic to several cancer cell lines. Inhibiting cell migration has gained considerable interest as an approach for discovering antimetastatic agents because this process is fundamental to metastasis. Piperlongumine, selected from cell-based assay screening of NuBBE Database, inhibited the migration of MDA-MB-231 breast cancer cells with an $\mathrm{EC}_{50}$ of $3.0 \pm 1.0 \mu \mathrm{M}$ by the Boyden chamber assay. A series of five analogous compounds based on the structure of piperlongumine were designed, synthesized and evaluated in cell migration and cytotoxicity assays. The analogue designed by molecular simplification $((E)-N$-acryloyl-3(3,4,5-trimethoxyphenyl)acrylamide) was the most active of the series, with an $\mathrm{EC}_{50}$ of $1.5 \pm 1 \mu \mathrm{M}$. Additionally, this compound was selectively cytotoxic, with a selectivity index (SI) of 4.4.
\end{abstract}

Keywords: piperlongumine, piplartine, piperamide, cytotoxicity, cell migration inhibition

\section{Introduction}

Metastasis is the process by which undifferentiated cancer cells migrate to other parts of the body. ${ }^{1,2}$ Suppression of metastasis is an urgent need in cancer treatment, as most existing drugs only inhibit cell proliferation. ${ }^{3}$ Traditionally, chemotherapy is based on cytotoxic therapeutic agents that inhibit proliferation and cause cell death. However, the strategy of inhibiting cell migration has recently gained considerable interest. ${ }^{4}$ Several compounds that inhibit the process of metastasis have been described to date. ${ }^{5,6}$ Paclitaxel, which was originally discovered as an

*e-mail: bolzaniv@iq.unesp.br antimitotic agent that disrupts the cell cycle in cancer cells by stabilizing microtubules, exhibits marked and selective inhibition of tumor cell migration. ${ }^{7}$

As extensively reviewed elsewhere, biodiversity in nature has provided unique chemical scaffolds that have been used as templates for medicinal chemistry and drug discovery. ${ }^{8-13}$ The availability of natural compound libraries is of significant importance for integrating natural products and medicinal chemistry, especially for the identification of new bioactive agents and the rational design of compounds in drug discovery. ${ }^{14}$ Within this context, we selected the natural product piperlongumine (1), also known as piplartine, from cell-based assay screening of NuBBE Database $\left(\mathrm{NuBBE}_{\mathrm{DB}}\right)^{15}$ and evaluated its ability to inhibit 
cancer cell migration using biological and target-based experiments.

Piperlongumine (1, Figure 1) is an alkamide isolated from several species of Piper (Piperaceae). ${ }^{16} \mathrm{It}$ is described as possessing antifungal properties, ${ }^{17}$ cytotoxicity toward several cancer cell lines, ${ }^{18,19}$ and trypanocidal effects, ${ }^{20}$ as well as other biological activities. ${ }^{21}$ Furthermore, piperlongumine selectively induces cell death in cancer cells but does not reduce viability in normal cells. ${ }^{22}$ This natural compound also demonstrates an interesting capacity to reduce angiogenesis and inhibit the formation of blood vessels in tumor xenografts in mice..$^{22,23}$ Recent work suggests that piperlongumine is more effective than paclitaxel in inhibiting tumor growth and presents excellent oral bioavailability. ${ }^{22}$ Piperlongumine causes an increase in reactive oxygen species (ROS) levels in cancer cells but not in normal cells, ${ }^{22}$ and piperlongumine analogues also enhanced ROS in PC-3 cells. ${ }^{24}$ This activity may be at least partly due to proteasome inhibition and may be responsible for the selective activity of piperlongumine..$^{25,26}$ Nonetheless, few studies to date have investigated the impact of this compound on cell migration..$^{27}$ Accordingly, we describe an analysis of piperlongumine as an inhibitor of the migration of breast cancer cell line MDA-MB-231 and an evaluation of its cytotoxicity toward normal and cancer cell lines. Additionally, we aimed at improving the biological activity of this compound through the design, synthesis and biological evaluation of a series of its derivatives.

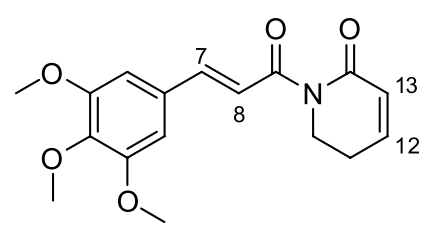

Piperlongumine (1)

Figure 1. Piperlongumine, a natural amide isolated from several species of Piper (Piperaceae).

\section{Results and Discussion}

The study of cell migration and its underlying mechanisms is of great significance in various fields, including cancer drug development. Tumor cell migration is one of the processes necessary for metastasis, and several approaches have been used to assess the ability of cells to cross tissue barriers. ${ }^{28}$ In this work, in vitro cell assays of a wound-healing ${ }^{29}$ and Boyden chamber ${ }^{30}$ method were performed to evaluate the ability of piperlongumine and its analogues (2-6) to inhibit the migration of MDA-MB-231 cancer cells. Those compounds with clearly observable activities were further subjected to cytotoxicity assays using the cancer cell lines MDA-MB-231 and DU-145, as well as the normal breast cell line (MCF10A), to further evaluate their toxicity toward and selectivity for malignant cells. ${ }^{31}$

Evaluation of piperlongumine activity as an inhibitor of tumor cell migration

\section{Wound-healing cell assay}

The wound-healing assay is a simple and effective in vitro method employed to qualitatively evaluate the influence of compounds on cell migration. Wounds are typically created by the removal of a portion of confluent cells growing in a multiwell plate using a pipette tip; closure of the uncovered area can then be observed and measured over time using microscopy or a computer imaging system. ${ }^{29}$ Positive activity is identified by measuring the area of the unclosed wound that remains. Piperlongumine at $10 \mu \mathrm{M}$ inhibited $97 \%$ of cell migration (Table 1). At this concentration, its activity was similar to the positive control colchicine, which inhibited $72 \%$ of cell migration at $1 \mu \mathrm{M}$ (Table 1).

\section{Boyden chamber cell assay}

Invasion of basement membranes by tumor cells and the cells' migration to distant tissues are crucial steps in the complex multistage process that leads to the formation of a metastasis. Tumor cells cross basement membranes, invade the lymphatic or vascular system during dissemination and then penetrate into a target tissue. The Boyden chamber assay employs a two-compartment system separated by a membrane to quantitatively evaluate the effect of compounds on the migration of cancer cells in vitro. ${ }^{28,30}$

Piperlongumine exhibited an $\mathrm{EC}_{50}$ of $3.0 \pm 1.0 \mu \mathrm{M}$ by the Boyden chamber assay, which is comparable to that of colchicine, $0.5 \pm 0.1 \mu \mathrm{M}$, as shown in Table 1 . These results indicate that piperlongumine possesses the ability to inhibit cell migration with similar potency as the positive control colchicine (Table 1). Furthermore, these results are in agreement with those obtained from wound-healing assays.

Table 1. Effects of piperlongumine and colchicine on MDA-MB-231 breast cancer cell migration

\begin{tabular}{lcc}
\hline Compound & $\begin{array}{c}\text { Wound healing } \\
\text { (concentration) } / \\
\% \text { inhibition }\end{array}$ & $\begin{array}{c}\text { Boyden chamber }{ }^{\mathrm{b}} \mathrm{EC}_{50} \\
/ \mu \mathrm{M}\end{array}$ \\
\hline Colchicine & $70(1 \mu \mathrm{M})$ & $0.5 \pm 0.1$ \\
Piperlongumine & $97(10 \mu \mathrm{M})$ & $3.0 \pm 1.0$ \\
\hline
\end{tabular}

${ }^{a}$ Average of three independent experiments; ${ }^{b}$ average of two independent experiments. 
Design and synthesis of compounds using the natural product piperlongumine as a scaffold

A series of synthesized piperlongumine analogues was recently reported, and it was proposed that the two reactive electrophilic sites are essential for the toxicity of these compounds. ${ }^{32}$ To enhance the compound's cell migration-inhibiting activity, a series of analogues were designed by taking into account information in the literature and concepts of molecular simplification and hybridization. Because the reported substitutions on the aromatic ring of the 3,4,5-trimethoxy cinnamic moiety do not affect the antitumor activity of the compound, we did not modify this part of the molecule. ${ }^{22,32}$ Additionally, considering that the double bond at $\mathrm{C} 12-\mathrm{C} 13$ is a key pharmacophore and that the double bond at $\mathrm{C} 7-\mathrm{C} 8$ plays a significant role in cell toxicity, ${ }^{32}$ we planned modifications of the $\delta$-valerolactam ring to study the effect of this scaffold on cell migration (2-4). Furthermore, we designed one compound using molecular simplification by retaining the Michael acceptor and the double bond at C12-C13, but by removing the lactam (piperidonic) ring (5). Finally, we used molecular hybridization to design a hybrid of piperlongumine and chromene (6), the latter of which is widely known for its cytotoxicity and induction of apoptosis. ${ }^{33}$ The designed compounds are presented in Scheme 1.

The synthesis of piperlongumine using different methods is described in the literature..$^{32,34-37}$ One of the newest and simplest approaches for amide bond formation consists of the coupling of the NH-lactam (piperidonic group) with 3,4,5-trimethoxy cinnamoyl chloride in the presence of a base. ${ }^{32}$ Accordingly, the designed compounds were synthesized in this way from the corresponding commercially available nitrogen-bearing reagents, as described in Scheme 2. ${ }^{32}$ The conditions that were able to enhance the nucleophilicity of the nitrogenous reagent, including the nature of the solvent, were dependent on the reactivity of this reagent. A detailed description of the synthetic methods together with their characterization is presented in Synthetic methods sub-section.

\section{Biological evaluation of the synthesized compounds}

All the synthesized compounds were evaluated by both the wound-healing and Boyden chamber assays as well as for their cytotoxicity toward MDA-MB-231, DU-145 and MCF10A cell lines. The results obtained are presented in Tables 2 to 4 .

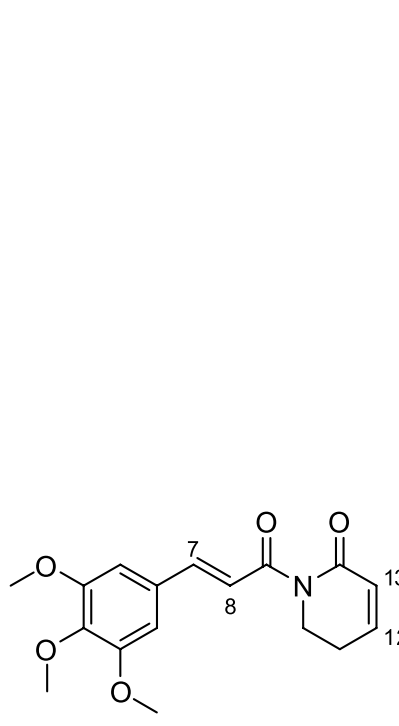

Piperlongumine (1)

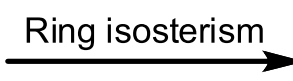<smiles>COc1cc(/C=C/C(=O)N2C(=O)C=CC2=O)cc(OC)c1OC</smiles><smiles>COc1cc(/C=C/C(=O)N2C(=O)c3ccccc3C2=O)cc(OC)c1OC</smiles><smiles>COc1cc(/C=C/C(=O)n2ccc3ccccc32)cc(OC)c1OC</smiles>

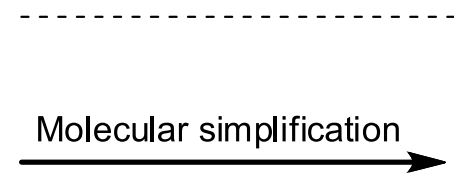<smiles>C=CC(=O)NC(=O)/C=C/c1cc(OC)c(OC)c(OC)c1</smiles>

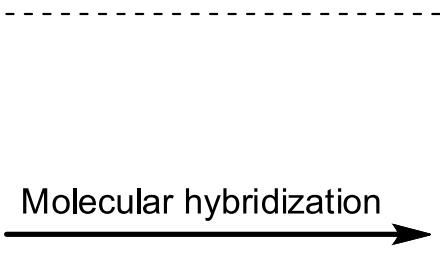<smiles>COc1cc(/C=C/C(=O)Nc2ccc3oc(=O)ccc3c2)cc(OC)c1OC</smiles>

Scheme 1. Piperlongumine (1) as the natural product model for compound design. 
<smiles>COc1cc(/C=C/C(=O)O)cc(OC)c1OC</smiles><smiles>[R]C(=O)/C=C/c1cc(OC)c(OC)c(OC)c1</smiles><smiles>CN1C(=O)C=CC1=O</smiles><smiles>O=C1c2ccccc2C(=O)N1c1ccccc1</smiles><smiles>c1ccc2cnccc2c1</smiles>

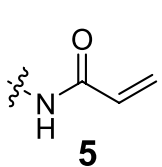<smiles>[Y][Y]([H])([H])Nc1ccc2oc(=O)ccc2c1</smiles>

Scheme 2. Synthesis of piperlongumine analogues 2-6. Reagents and conditions: (a) $(\mathrm{COCl})_{2}, \mathrm{DMF}$ (cat.), $\mathrm{CH}_{2} \mathrm{Cl}_{2}$, r.t., 2 h; (b) described in Synthetic methods sub-section.

Table 2. Effects of piperlongumine analogues (2-6) on the results of wound-healing (MDA-MB-231 cells) assays

\begin{tabular}{lc}
\hline Compound & Inhibition of cell migration at $10 \mu \mathrm{M} / \%$ \\
\hline $\mathbf{2}$ & 0 \\
$\mathbf{3}$ & 0 \\
$\mathbf{4}$ & 50 \\
$\mathbf{5}$ & 97 \\
$\mathbf{6}$ & 0 \\
Colchicine & $70^{\mathrm{a}}$ \\
Piperlongumine & 97 \\
\hline
\end{tabular}

${ }^{\mathrm{a} E v a l u a t e d}$ at $1 \mu \mathrm{M}$.

The analogue designed by molecular simplification (5) was highly active, inhibiting $97 \%$ of MDA-MB-231 cell migration at $10 \mu \mathrm{M}$. Compound $\mathbf{4}$ presented moderate activity, with only $50 \%$ inhibition of cell migration at $10 \mu \mathrm{M}$. The other synthesized compounds presented no activity at the concentration range evaluated in this assay. The most promising designed compound (5) maintains the biological activity of piperlongumine while possessing a simpler structure.

According to the Boyden chamber assay, compound $\mathbf{5}$ has an $\mathrm{EC}_{50}$ of $1.5 \pm 1.0 \mu \mathrm{M}$, which is comparable to the $\mathrm{EC}_{50}$ of colchicine $(0.5 \pm 0.1 \mu \mathrm{M})$, as presented in Table 3 . Interestingly, compound $\mathbf{5}$ displays increased inhibition capacity compared to the original parent compound piperlongumine.

Piperlongumine and $\mathbf{5}$ display selective toxicity toward the normal breast cell line MCF10A. Compound 5 inhibits the
Table 3. Effects of 5 and colchicine on MDA-MB-231 breast cancer cell migration

\begin{tabular}{lcc}
\hline Compound & $\begin{array}{c}\text { Wound healing } / \\
(\% \text { inhibition at } 10 \mu \mathrm{M})\end{array}$ & $\begin{array}{c}\text { Boyden chamber } \\
\mathrm{EC}_{50} / \mu \mathrm{M}\end{array}$ \\
\hline Colchicine & 70 & $0.5 \pm 0.1$ \\
$\mathbf{5}$ & 97 & $1.5 \pm 1.0$ \\
\hline
\end{tabular}

${ }^{a}$ Average of three independent experiments; baverage of two independent experiments.

growth of MDA-MB-231 cells with an $\mathrm{EC}_{50}$ of $9.0 \pm 1.0 \mu \mathrm{M}$ and that of normal MCF10A cells with an $\mathrm{EC}_{50}$ of $40 \pm 5 \mu \mathrm{M}$. The degree of selectivity can be expressed as the selectivity index $\left(\mathrm{SI}=\mathrm{EC}_{50}\right.$ for the normal breast cell line $\mathrm{MCF} 10 \mathrm{~A} / \mathrm{EC}_{50}$ for the cancer cell line MDA-MB-231), which is 4.4 for compound 5. Piperlongumine has a similar effect, with an $\mathrm{EC}_{50}$ of $7.0 \pm 1.0 \mu \mathrm{M}$ against MDA-MB-231 breast cancer cells and an $\mathrm{EC}_{50}$ of $38 \pm 8 \mu \mathrm{M}$ against MCF10A normal breast cells, corresponding to an SI of 5.4 (Table 4). The cytotoxicity evaluation shows that compound $\mathbf{5}$ and piperlongumine have greater cytotoxic effects $\left(\mathrm{EC}_{50}\right.$ values) compared to effects on cell migration, suggesting that their inhibition of cell migration may not be due to their toxicity.

\section{Tubulin polymerization assay}

Microtubules are essential for the development and maintenance of cell shape, division and mitosis and are also involved in cell signalling and the transport of vesicles, mitochondria and other components inside cells. ${ }^{38-44}$ Microtubules are formed via a dynamic process of polymerization and depolymerization of

Table 4. Cytotoxicities of piperlongumine and 5 against MDA-MB-231, DU-145 and MCF10A cell lines

\begin{tabular}{lcccc}
\hline Compound & $\mathrm{EC}_{50} \mathrm{MDA}-\mathrm{MB}-231 / \mu \mathrm{M}$ & $\mathrm{EC}_{50} \mathrm{DU}-145 / \mu \mathrm{M}$ & $\mathrm{EC}_{50} \mathrm{MCF} 10 \mathrm{~A} / \mu \mathrm{M}$ & Selectivity index $(\mathrm{SI})$ \\
\hline Doxorubicin & $3.0 \pm 1.0$ & $5.5 \pm 0.5$ & $30 \pm 8$ & 10 \\
Piperlongumine & $7.0 \pm 1.0$ & $11.0 \pm 3.0$ & $38 \pm 8$ & 5.4 \\
$\mathbf{5}$ & $9.0 \pm 1.0$ & $12.0 \pm 1.0$ & $40 \pm 5$ & 4.4 \\
\hline
\end{tabular}


heterodimers formed by $\alpha$ - and $\beta$-tubulin proteins. ${ }^{42,44,45}$ Due to their essential role during cellular division processes, microtubules are among the most common and effective targets in cancer cells.

Recent studies have reported the ability of arylsubstituted piperlongumine analogues to inhibit microtubule polymerization in vitro. ${ }^{46}$ However, other independent studies of piperlongumine and similar derivatives have demonstrated substantial anti-inflammatory activity for this class of compounds. Based on these facts and the interesting potential of microtubules as an anticancer target, we performed fluorescence-based in vitro studies to evaluate the ability of piperlongumine to inhibit microtubule formation and to characterize this system as a possible molecular mechanism explaining the activity of this molecule and its derivatives.

The evaluation of microtubule polymerization in the presence of different concentrations of piperlongumine is shown in Figure 2.

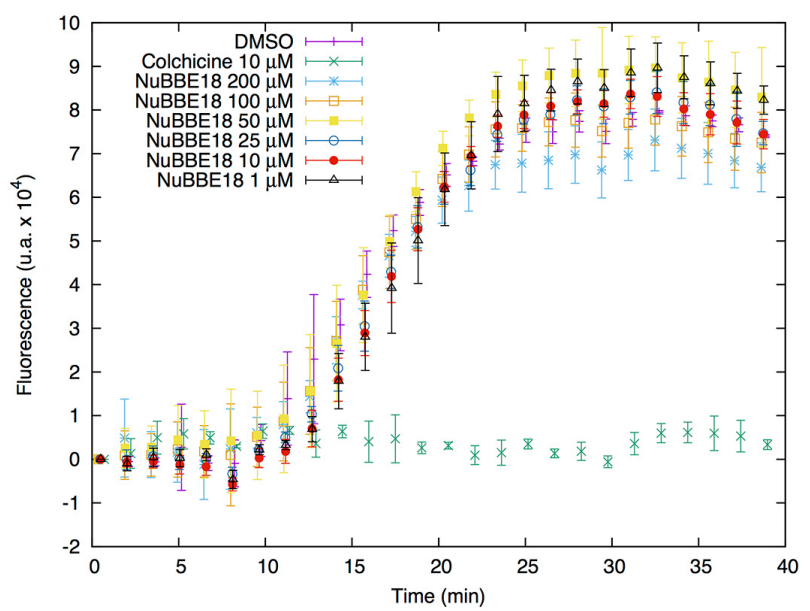

Figure 2. Fluorescence-based microtubule polymerization assays in the presence of different concentrations of piperlongumine (from 1 to $200 \mu \mathrm{M}$ ). DMSO and colchicine at $10 \mu \mathrm{M}$ were used as negative and positive controls, respectively, for polymerization inhibition. The data correspond to the average value of three independent replicates.

Although colchicine completely inhibited microtubule formation at a concentration of $10 \mu \mathrm{M}$, piperlongumine did not affect the formation of microtubules in vitro over a range of 1 to $200 \mu \mathrm{M}$. These results indicate that piperlongumine does not interact with tubulin and is unable to modulate microtubule polymerization. Accordingly, the findings suggest a different mechanism underlying the anticancer activity of piperlongumine and its derivatives, which may be related to anti-inflammatory effects. ${ }^{47,48}$

\section{Conclusions}

This work represents an interesting example of the significant structural variability in natural products and the usefulness of this variability in drug discovery. Piperlongumine, which was selected among many natural compounds already identified and available in $\mathrm{NuBBE}_{\mathrm{DB}}$, inhibited migration of the breast cancer cell line MDA-MB-231 with an $\mathrm{EC}_{50}$ of $3 \pm 1 \mu \mathrm{M}$ by the Boyden chamber assay. Additionally, we designed and synthesized five analogues of piperlongumine through molecular simplification. Among these compounds, $\mathbf{5}$ was the most active, with an $\mathrm{EC}_{50}$ of $1.5 \pm 1 \mu \mathrm{M}$ against breast cancer cell MDA-MB-231 migration by the Boyden chamber assay. Additionally, we evaluated the cytotoxicity of these compounds, and both piperlongumine and $\mathbf{5}$ presented high selectivity for tumor cells, with a selectivity index of 4.44 and 5.42, respectively. Furthermore, taking into account the reported activities of piperlongumine as an antiinflammatory agent and inhibitor of microtubule activity, we evaluated the ability of this compound to modulate tubulin polymerization in vitro. The results suggest that piperlongumine does not interact with microtubules and that its activity is likely related to another molecular mechanism.

\section{Experimental}

Isolation of piperlongumine (1)

The fruits of Piper tuberculatum were harvested from a specimen growing under greenhouse conditions at the Institute of Chemistry (UNESP, Araraquara, São Paulo State, Brazil) in January of 2012. The botanical material was properly identified by Dr Guillermo E. D. Paredes from the University Pedro Ruiz Gallo in Peru. A voucher specimen (K-167) was deposited in the herbarium of the Institute of Botany of São Paulo in São Paulo, Brazil. The dried fruits $(803 \mathrm{~g})$ were extracted by maceration with dichloromethane:methanol $(2: 1,3 \times 1200 \mathrm{~mL})$ under ultrasonication. The residue was concentrated under vacuum to obtain $48.90 \mathrm{~g}$ of extract $(6.1 \%)$. The whole extract was first fractioned under low pressure by normalphase column chromatography with silica gel (70 mesh) as the stationary phase $(63 \mu \mathrm{M}, 300 \times 60 \mathrm{~mm})$. The solvent system was a mixture of (A) $n$-hexane and (B) ethyl acetate in a gradient from 5 to $50 \% \mathrm{~B}$, which afforded 11 fractions. Fraction 3 formed a precipitate, which was filtered and washed with $\mathrm{MeOH}$ in an ice bath to furnish piperlongumine (1, $1.19 \mathrm{~g}) .{ }^{1} \mathrm{H}$ NMR $\left(600 \mathrm{MHz}, \mathrm{CDCl}_{3}\right)$ $\delta(\mathrm{ppm}) 2.43(2 \mathrm{H}, \mathrm{m}, J 6.3,4.3,1.8 \mathrm{~Hz}), 3.82(3 \mathrm{H}, \mathrm{s}), 3.84$ $(6 \mathrm{H}, \mathrm{s}), 3.99(2 \mathrm{H}, \mathrm{t}, J 6.5 \mathrm{~Hz}), 5.99(1 \mathrm{H}, \mathrm{dt}, J 9.7,1.7 \mathrm{~Hz})$, $6.75(2 \mathrm{H}, \mathrm{s}), 6.89(1 \mathrm{H}, \mathrm{dt}, J 9.4,4.1 \mathrm{~Hz}), 7.37(1 \mathrm{H}, \mathrm{d}$, $J 15.5 \mathrm{~Hz}), 7.62(1 \mathrm{H}, \mathrm{d}, J 15.5 \mathrm{~Hz})$. 


\section{Cell assays}

\section{Cell cultures}

MDA-MB-231 human breast cancer cells were cultured at $37{ }^{\circ} \mathrm{C}$ and $5 \% \mathrm{CO}_{2}$ in Leibovitz's medium, and MCF-7 human breast cancer cells were cultured in DMEM (Dulbecco's modified Eagle's medium, Cultilab) at $37{ }^{\circ} \mathrm{C}$ and $5 \% \mathrm{CO}_{2}$. DU-145 human prostate tumor cells were cultured under the same conditions using RPMI (Roswell Park Memorial Institute medium). The cells were stored in liquid nitrogen in culture medium containing 5\% DMSO and $20 \%$ foetal bovine serum (FBS, sterile, Cultilab).

\section{Wound-healing assay}

A wound-healing assay was performed to qualitatively assess the potential of the compounds to inhibit cell migration. ${ }^{29}$ Cells were cultured in 24 -well plates $\left(1 \times 10^{5}\right.$ cells per well) containing $1 \mathrm{~mL}$ of culture medium and $10 \% \mathrm{FBS}$. After the cells reached confluence, the culture medium was removed, and a wound was generated in the cell monolayer with the aid of a sterile pipette tip. The test compounds were dissolved in DMSO, diluted in the culture medium and added to each well (final DMSO concentration $=0.1 \%$ ). The system was photographed using a Nikon Eclipse TS100 inverted microscope (4× magnification, Nikon Instruments Inc., Melville, NY, USA); images were taken at $0 \mathrm{~h}$ and after $22 \mathrm{~h}$ of incubation at $37^{\circ} \mathrm{C}$ and $5 \% \mathrm{CO}_{2}$. The percent inhibition shown by the test compound was determined by the difference in the wound area at 0 and $22 \mathrm{~h}$. The extent of the area was measured using NIS - Elements software. The assays were performed in triplicate, with colchicine as a positive control and DMSO as a negative control. ${ }^{29}$

\section{Boyden chamber assay}

The Boyden chamber assay was performed to quantitatively evaluate the effect of the compounds on cell migration. ${ }^{28,30}$ This assay utilizes a hollow plastic chamber that is sealed at one end with a porous membrane. This chamber/insert is suspended over a larger well that contains medium and a chemoattractant. Cells are placed inside the insert and allowed to migrate through the pores from one side of the membrane to the other. Migratory cells are then stained and counted. The assays were performed in 24-well plates (BD BioCoat ${ }^{\mathrm{TM}}$ Migration/Invasion Chambers) with inserts of $6.5 \mathrm{~mm}$ diameter and $8 \mu \mathrm{M}$ pore size. To the inner part of the insert (upper chamber), $4 \times 10^{4}$ cells $/ 300 \mu \mathrm{L}$ culture medium (without FBS) and the test compound were added; to the lower compartment (well of the plate), $700 \mu \mathrm{L}$ of culture medium supplemented with $10 \%$ FBS and the test compound were added. This system was incubated for $6 \mathrm{~h}$ at $37{ }^{\circ} \mathrm{C}$ and $5 \% \mathrm{CO}_{2}$. After incubation, the medium in the insert was removed along with the cells that had not migrated to the bottom of the membrane. The cells that had migrated to the lower portion of the membrane were fixed and stained with $1 \%$ aqueous toluidine blue in borax for $5 \mathrm{~min}$. The membranes were cut using a surgical lancet and placed on a slide, and the migrated cells were counted using a Nikon Eclipse E600 optical microscope (Nikon Instruments Inc., Melville, NY, USA) and NIS-Elements Image processing software. The assays were performed in duplicate using colchicine as a positive control and DMSO as a negative control. The $\mathrm{EC}_{50}$ was determined from the curve of the log concentration versus the percent inhibition. The curves were plotted using data obtained for six different concentrations of the compounds tested in duplicate. The curves were fitted using the software Sigmaplot 11.0 by the method of nonlinear regression - dynamic fitting.

\section{Cytotoxicity assay}

A cytotoxicity evaluation was performed to test the toxicity of the compounds toward the cancer cell lines MDA-MB- 231 and DU-145. The assay was performed in 96-well plates to which approximately $5 \times 10^{3}$ cells per well were added. After checking cell adhesion (at approximately 24 hours), piplartine was dissolved in DMSO in a concentration of $100 \mathrm{mM}$ (stock solution). For the assay, compounds were added into wells in serial dilutions (100-0.04 $\mu \mathrm{M})$. The plate was incubated for $24 \mathrm{~h}$, after which $20 \mu \mathrm{L}$ of 3-(4,5-dimethylthiazol-2-yl)-5-(3carboxymethoxyphenyl)-2-(4-sulfophenyl)-2H-tetrazolium (MTS) was added to each well. After $4 \mathrm{~h}$ of incubation, the absorbance was measured at $490 \mathrm{~nm}$ using a SpectraMax Plus 384 - Absorbance Microplate Reader (Molecular Devices, Sunnyvale, USA). The plate was maintained at $24^{\circ} \mathrm{C}$, and the assays were performed in triplicate using doxorubicin as a positive control and DMSO as a negative control. ${ }^{31}$

\section{Tubulin polymerization assay (fluorescence based)}

A fluorescence-based assay was applied (Cytoskeleton Inc., Denver, CO, USA) to determine the $\mathrm{EC}_{50}$ of effects on tubulin polymerization. ${ }^{49-52}$

Microtubule-associated, protein-rich tubulin protein ( $2 \mathrm{mg} \mathrm{mL}^{-1}$, porcine, cytoskeleton) in a buffer containing $80 \mathrm{mM}$ piperazine- $N, N$ '-bis[2-ethanesulfonic acid] sequisodium salt (PIPES) at pH 6.9, $2.0 \mathrm{mM}$ magnesium chloride, $0.5 \mathrm{mM}$ ethylene glycol-bis( $\beta$-amino-ethyl ether) $N, N, N$ ', $N$ '-tetra-acetic acid (EGTA), $1.0 \mathrm{mM}$ guanosine triphosphate (GTP) and $10 \%$ glycerol was placed in each well of a 96-well plate (OptiPlate F -1536 - Black; PerkinElmer Inc., Waltham, MA, USA). For each assay, $45 \mu \mathrm{L}$ of the tubulin solution was incubated with $5 \mu \mathrm{L}$ of the compound at a 10-fold concentration and $10 \%$ dimethyl 
sulfoxide (DMSO), resulting in a final solution with the desired concentration of $1 \%$ DMSO. ${ }^{49}$ All assays were performed in triplicate, with $1 \%$ DMSO as the negative control and $10 \mu \mathrm{M}$ colchicine as the positive control. Using an excitation wavelength of $360 \mathrm{~nm}$, the rate of polymerization was monitored at $37^{\circ} \mathrm{C}$ by measuring the fluorescence emission at $440 \mathrm{~nm}$ with a Victor 3 fluorimeter plate reader and Wallac 1420 Multilabel Plate Counter software (PerkinElmer Inc., Waltham, MA, USA).

\section{Materials and instruments}

Reagents were purchased from Sigma-Aldrich, Acros Organics, or Fluka and were used without further purification; solvents were purified according to standard methods. ${ }^{53}$ Reaction progress was monitored by thin layer chromatography (TLC) on aluminium plates pre-coated with silica gel F254 layers ( $0.2 \mathrm{~mm}$ thickness; Whatman) and visualized under UV light (254 and $366 \mathrm{~nm}$ ). Column chromatography was carried out over silica gel (particle size of 35-70 $\mu \mathrm{M}$; Acros Organics). ${ }^{1} \mathrm{H}$ NMR spectra were recorded using Bruker AC 300 (300 MHz), Bruker Avance $400(400 \mathrm{MHz})$ or Bruker Avance III 600 (600 MHz) spectrometers; spectra were referenced against the internal standard TMS $\left(\delta_{\mathrm{TMS}} 0.00\right)$ or against the residual solvent resonances of $\mathrm{CDCl}_{3}\left(\delta 7.26{ }^{1} \mathrm{H}\right)$; the multiplicity (s, singlet; d, doublet; t, triplet; q, quartet; dd, doublet of doublet) and coupling constant $(\mathrm{Hz})$ are noted. ${ }^{13} \mathrm{C}$ NMR spectra were recorded using Bruker AC $300(75 \mathrm{MHz})$ or Bruker Avance III 600 (150 MHz) spectrometers. ${ }^{13} \mathrm{C}$ NMR chemical shifts are reported in parts per million relative to the solvent. All ${ }^{13} \mathrm{C}$ NMR spectra were determined with broadband decoupling. When necessary, the structures of the compounds were verified and the signals unambiguously assigned by 2D NMR techniques: ${ }^{1} \mathrm{H}-{ }^{1} \mathrm{H}$ COSY (correlation spectroscopy), ${ }^{1} \mathrm{H}-{ }^{1} \mathrm{H}$ NOESY (nuclear Overhauser effect spectroscopy), ${ }^{13} \mathrm{C}-{ }^{1} \mathrm{H}$ HMQC (heteronuclear multiple quantum correlation), and ${ }^{13} \mathrm{C}-{ }^{1} \mathrm{H}$ HMBC (heteronuclear multiple bond correlation). Some ${ }^{13} \mathrm{C}$ values were assigned using evidence from $\mathrm{HMBC}$ and are marked with an asterisk in Synthetic methods sub-section. Electrospray ionization time-of-flight (ESI-TOF) high-resolution mass spectra (HRMS) were measured using a MicrOTOF Q II spectrometer (Bruker Daltonics, Billerica, MA, USA) operating in positive ion mode. ChemDraw Ultra 8.0 was used to calculate the values of the pseudo-molecular ions $[\mathrm{M}+\mathrm{H}]^{+}$and $[\mathrm{M}+\mathrm{Na}]^{+}$.

\section{Synthetic methods}

(E)-3-(3,4,5-Trimethoxyphenyl)acryloyl chloride (7)

To a solution of (E)-3,4,5-trimethoxycinnamic acid
(200 mg, $0.84 \mathrm{mmol}$ ) in $\mathrm{CH}_{2} \mathrm{Cl}_{2}(8.0 \mathrm{~mL}$ ) under a nitrogen atmosphere was added oxalyl chloride ( $358 \mu \mathrm{L}, 4.2 \mathrm{mmol})$ and a catalytic amount of dimethylformamide (DMF). The reaction was stirred at room temperature for 2 hours. The residue, compound $\mathbf{7}$, a yellow solid, was dried and used in the next step without further purification. ${ }^{32}$

1-((E)-3-(3,4,5-Trimethoxyphenyl)acryloyl)-1 H-pyrrole-2,5dione (2)

$\mathrm{CH}_{2} \mathrm{Cl}_{2}(8 \mathrm{~mL})$, triethylamine $(352 \mu \mathrm{L}, 2.52 \mathrm{mmol})$, and maleimide ( $96 \mathrm{mg}, 1 \mathrm{mmol}$ ) were added to $7(0.84 \mathrm{mmol})$. The reaction mixture was stirred at room temperature overnight and then quenched by addition of a saturated aqueous ammonium chloride solution. The product was extracted with $\mathrm{CH}_{2} \mathrm{Cl}_{2}$; the combined extracts were dried over $\mathrm{MgSO}_{4}$ and filtered, and the solvent was removed under reduced pressure. ${ }^{32}$ The product was purified by column chromatography using cyclohexane:ethyl acetate (7:3) for elution to afford compound 2 (121 $\mathrm{mg}, 45 \%$ yield) as a pure reddish-brown solid. ${ }^{1} \mathrm{H}$ NMR (400 MHz, $\left.\mathrm{CDCl}_{3}\right) \delta(\mathrm{ppm}) 3.94(\mathrm{~s}, 3 \mathrm{H}), 3.95(\mathrm{~s}, 6 \mathrm{H}), 6.88(\mathrm{~s}$, 2H), $6.92(\mathrm{~s}, 2 \mathrm{H}), 7.23(\mathrm{~d}, 1 \mathrm{H}, J 15.5 \mathrm{~Hz}), 7.91(\mathrm{~d}, 1 \mathrm{H}$, $J 15.5 \mathrm{~Hz}) ;{ }^{13} \mathrm{C}$ NMR $\left(75 \mathrm{MHz}, \mathrm{CDCl}_{3}\right) \delta 56.2,61.0$, 106.0, 117.9, 129.6, 135.4, 141.0*, 148.4, 153.5, 162.5*, 167.9; Figures S1-S3 in Supplementary Information; HRMS (ESI-TOF) $\mathrm{m} / \mathrm{z}$ : $318.0977[\mathrm{M}+\mathrm{H}]^{+}$(calcd. for $\mathrm{C}_{16} \mathrm{H}_{16} \mathrm{NO}_{6}, 318.0972$ ), $340.0796[\mathrm{M}+\mathrm{Na}]^{+}$(calcd. for $\mathrm{C}_{16} \mathrm{H}_{15} \mathrm{NNaO}_{6}, 340.0792$ ).

2-((E)-3-(3,4,5-Trimethoxyphenyl)acryloyl)isoindoline-1,3dione (3)

$\mathrm{CH}_{2} \mathrm{Cl}_{2}(8 \mathrm{~mL})$, triethylamine $(352 \mu \mathrm{L}, 2.52 \mathrm{mmol})$, and phthalimide (147 mg, $1 \mathrm{mmol}$ ) were added to 7 $(0.84 \mathrm{mmol})$. The reaction mixture was stirred at room temperature overnight and then quenched by addition of a saturated aqueous ammonium chloride solution. The product was extracted with $\mathrm{CH}_{2} \mathrm{Cl}_{2}$; the combined extracts were dried over $\mathrm{MgSO}_{4}$ and filtered, and the solvent was removed under reduced pressure. ${ }^{32}$ The residue was purified by column chromatography using cyclohexane:ethyl acetate (7:3) for elution to afford compound $\mathbf{3}$ (121 mg, 40\% yield) as a pure light yellow solid. ${ }^{1} \mathrm{H}$ NMR (600 MHz, $\mathrm{CDCl}_{3}$ ) $\delta 3.90$ (s, 3H), 3.92 (s, 6H), $6.86(\mathrm{~s}, 2 \mathrm{H}), 7.28(\mathrm{~d}, 1 \mathrm{H}, J 15.5 \mathrm{~Hz}), 7.86$ (dd, $2 \mathrm{H}, J 5.5,3.0 \mathrm{~Hz}), 7.90(\mathrm{~d}, 1 \mathrm{H}, J 15.5 \mathrm{~Hz}), 8.00(\mathrm{dd}, 2 \mathrm{H}$, $J$ 5.5, 3.0 Hz); ${ }^{13} \mathrm{C} \mathrm{NMR}\left(150 \mathrm{MHz}, \mathrm{CDCl}_{3}\right) \delta 56.2,61.0$, 106.0, 118.7, 124.4, 129.7, 131.4, 135.4, 141.0, 147.9, 153.5, 163.7, 165.7; Figures S4-S6 in Supplementary Information; HRMS (ESI-TOF) $m / z: 368.1132[\mathrm{M}+\mathrm{H}]^{+}$ (calcd. for $\mathrm{C}_{20} \mathrm{H}_{18} \mathrm{NO}_{6}, 368.1129$ ), $390.0948[\mathrm{M}+\mathrm{Na}]^{+}$ (calcd. for $\mathrm{C}_{20} \mathrm{H}_{17} \mathrm{NNaO}_{6}, 390.0948$ ). 
(E)-1-(1H-Indol-1-yl)-3-(3,4,5-trimethoxyphenyl)prop-2-en1-one (4)

$\mathrm{CH}_{2} \mathrm{Cl}_{2}(4 \mathrm{~mL}$ ), sodium hydride ( $33 \mathrm{mg}, 0.84 \mathrm{mmol}$ ), and indole ( $59 \mathrm{mg}, 0.5 \mathrm{mmol})$ were added to $7(0.42 \mathrm{mmol})$. The reaction mixture was stirred at room temperature overnight and then quenched by addition of a saturated aqueous ammonium chloride solution. The product was extracted with $\mathrm{CH}_{2} \mathrm{Cl}_{2}$; the combined extracts were dried over $\mathrm{MgSO}_{4}$ and filtered, and the solvent was removed under reduced pressure. ${ }^{32}$ The residue was purified by column chromatography using cyclohexane:ethyl acetate (7:3) for elution to afford compound 4 (58 $\mathrm{mg}, 41 \%$ yield) as a pure reddish-brown solid. ${ }^{1} \mathrm{H}$ NMR $(400 \mathrm{MHz}$, $\left.\mathrm{CDCl}_{3}\right) \delta 3.96(\mathrm{~s}, 3 \mathrm{H}), 3.99(\mathrm{~s}, 6 \mathrm{H}), 6.74(\mathrm{~d}, 1 \mathrm{H}, J 3.7 \mathrm{~Hz})$, $6.89(\mathrm{~s}, 2 \mathrm{H}), 7.16(\mathrm{~d}, 1 \mathrm{H}, J 15.3 \mathrm{~Hz}), 7.32(\mathrm{dd}, 1 \mathrm{H}, J$ 8.0, $7.8 \mathrm{~Hz}), 7.41(\mathrm{dd}, 1 \mathrm{H}, J 8.2,8.0 \mathrm{~Hz}), 7.63(\mathrm{~d}, 1 \mathrm{H}, J 7.8 \mathrm{~Hz})$, $7.69(\mathrm{~d}, 1 \mathrm{H}, J 3.7 \mathrm{~Hz}), 7.94(\mathrm{~d}, 1 \mathrm{H}, J 15.3 \mathrm{~Hz}), 8.57$ (d, $1 \mathrm{H}, J 8.2 \mathrm{~Hz}) ;{ }^{13} \mathrm{C} \mathrm{NMR}\left(75 \mathrm{MHz}, \mathrm{CDCl}_{3}\right) \delta 56.3,61.0$, $105.6,109.2,116.4,116.9,120.9,123.8,124.6,125.1$, $129.9^{*}, 130.5^{*}, 135.8^{*}, 140.5^{*}, 146.7,153.5,164.2^{*}$; Figures S7-S9 in Supplementary Information; HRMS (ESI-TOF) $m / z: 338.1386[\mathrm{M}+\mathrm{H}]^{+}$(calcd. for $\mathrm{C}_{20} \mathrm{H}_{20} \mathrm{NO}_{4}$, 338.1387), $360.1219[\mathrm{M}+\mathrm{Na}]^{+}$(calcd. for $\mathrm{C}_{20} \mathrm{H}_{19} \mathrm{NNaO}_{4}$, 360.1206).

\section{(E)-N-Acryloyl-3-(3,4,5-trimethoxyphenyl)acrylamide (5)}

To a solution of acrylamide $(710 \mathrm{mg}, 10 \mathrm{mmol})$ in THF $(50 \mathrm{~mL})$ at $-78{ }^{\circ} \mathrm{C}, n$-BuLi $(4.8 \mathrm{~mL}, 12 \mathrm{mmol} ; 2.5 \mathrm{M}$ in $n$-hexane) was added dropwise. The reaction mixture was warmed to room temperature, and the reaction proceeded for 7 hours. The reaction mixture was cooled to $-78{ }^{\circ} \mathrm{C}$, and a solution of 7 (20 mmol) in THF $(28 \mathrm{~mL})$ was added dropwise. The reaction was warmed to room temperature, allowed to proceed for 15 hours and then quenched by addition of a saturated aqueous ammonium chloride solution. The reaction mixture was extracted with diethyl ether; the combined organic extracts were washed with a saturated solution of sodium chloride, dried over $\mathrm{MgSO}_{4}$, filtered and evaporated to dryness under vacuum. The residue was purified by successive recrystallization from ethyl ether $(30 \mathrm{~mL})$ and subsequently with ethanol $(70 \mathrm{~mL})$ to afford compound $\mathbf{5}$ (920 mg, 30\% yield) as a pure yellow solid. ${ }^{37} \mathrm{H}$ NMR $\left(600 \mathrm{MHz}, \mathrm{CDCl}_{3}\right) \delta 3.89$ (s, 3H), 3.90 (s, $6 \mathrm{H}), 5.94(\mathrm{dd}, 1 \mathrm{H}, J 10.5,1.2 \mathrm{~Hz}), 6.56(\mathrm{dd}, 1 \mathrm{H}, J, 16.6$, $1.2 \mathrm{~Hz}), 6.77$ (dd, 1H, J 16.6, 10.5 Hz), 6.83 (s, 2H), 7.31 (d, $1 \mathrm{H}, J 15.6 \mathrm{~Hz}), 7.79$ (d, 1H, J 15.6 Hz), 9.17 (s, 1H); ${ }^{13} \mathrm{C}$ NMR $\left(150 \mathrm{MHz}, \mathrm{CDCl}_{3}\right) \delta 56.2,61.0,105.8,118.6$, $129.8,130.3,131.2,140.6,146.5,153.4,165.6,166.9$; Figures S10-S12 in Supplementary Information; HRMS (ESI-TOF) $m / z: 292.1188[\mathrm{M}+\mathrm{H}]^{+}$(calcd. for $\mathrm{C}_{15} \mathrm{H}_{18} \mathrm{NO}_{5}$, 292.1179), $314.1016[\mathrm{M}+\mathrm{Na}]^{+}$(calcd. for $\mathrm{C}_{15} \mathrm{H}_{17} \mathrm{NNaO}_{5}$,
314.0999). The synthesis of this compound by a similar method was recently described. ${ }^{54}$

(2E)-3-(3,4,5-Trimethoxyphenyl)-N-(2-oxo-2H-chromen-6yl)acrylamide (6)

$\mathrm{CH}_{2} \mathrm{Cl}_{2}(1 \mathrm{~mL})$, triethylamine $(352 \mu \mathrm{L}, 2.52 \mathrm{mmol})$, and 6-amino-chromen-2-one (161 mg, $1 \mathrm{mmol})$ were added to $7(0.84 \mathrm{mmol})$. The reaction mixture was stirred at room temperature for 2 hours and then quenched by addition of a saturated aqueous ammonium chloride solution. The product was extracted with ethyl acetate; the combined extracts were dried over $\mathrm{MgSO}_{4}$ and filtered, and the solvent removed under reduced pressure. ${ }^{32}$ The residue was purified by column chromatography using an $n$-hexane:ethyl acetate gradient from 7:3 to 0:1 for elution to afford compound $\mathbf{6}(80 \mathrm{mg}$, $21 \%$ yield) as a pure light yellow solid. ${ }^{32}{ }^{1} \mathrm{H} \mathrm{NMR}(600 \mathrm{MHz}$, $\left.\mathrm{CDCl}_{3}\right) \delta 3.89(\mathrm{~s}, 3 \mathrm{H}), 3.91(\mathrm{~s}, 6 \mathrm{H}), 6.47(\mathrm{~d}, 1 \mathrm{H}, J 9.5 \mathrm{~Hz})$, $6.54(\mathrm{~d}, 1 \mathrm{H}, J 15.3 \mathrm{~Hz}), 6.78$ (s, 2H), $7.30(\mathrm{~d}, 1 \mathrm{H}, J 8.9 \mathrm{~Hz})$, 7.51 (dd, 1H, J 8.9, $2.5 \mathrm{~Hz}), 7.71(\mathrm{~d}, 1 \mathrm{H}, J 15.3 \mathrm{~Hz}), 7.73$ (d, 1H, J 9.5 Hz), 7.81 (s, 1H), 8.18 (bs, 1H; obs.: broad signal); $\left.{ }^{13} \mathrm{C} \mathrm{NMR} \mathrm{(150} \mathrm{MHz,} \mathrm{CDCl}_{3}\right) \delta 56.2,61.0,105.3$, $117.2,117.3,118.5,119.1,119.6,123.5,129.9,134.6,140.1$, 142.9, 143.5, 150.5, 153.5, 160.8, 164.1; Figures S13-S15 in Supplementary Information; HRMS (ESI-TOF) $m / z: 382.1285[\mathrm{M}+\mathrm{H}]^{+}$(calcd. for $\mathrm{C}_{21} \mathrm{H}_{20} \mathrm{NO}_{6}, 382.1285$ ), 404.1097 [M + Na $]^{+}$(calcd. for $\mathrm{C}_{21} \mathrm{H}_{19} \mathrm{NNaO}_{6}, 404.1105$ ).

\section{Supplementary Information}

Supplementary information (NMR spectra) is available free of charge at http://jbcs.sbq.org.br as PDF file.

\section{Acknowledgments}

This work was supported by the State of São Paulo Research Foundation (FAPESP, Fundação de Amparo à Pesquisa do Estado de São Paulo), grant No. 2013/07600-3; Biota-FAPESP, grant No. 2003/02176-7; SISBIOTACNPq-FAPESP, grant No. 2010/52327-5; Coordenação de Aperfeiçoamento de Pessoal de Nível Superior (CAPES) and Conselho Nacional de Desenvolvimento Científico e Tecnológico (CNPq). The researchers also acknowledge scholarships, grant No. 2010/17329-7, No. 2010/06741-4 and No. 2007/56140-4 from the São Paulo Research Foundation (FAPESP).

\section{References}

1. Steeg, P. S.; Nat. Med. 2006, 12, 895.

2. Chang, T. T.; More, S. V.; Lu, I. H.; Hsu, J. C.; Chen, T. J.; Jen, Y. C.; Lu, C. K.; Li, W. S.; Eur. J. Med. Chem. 2011, 46, 3810. 
3. Weber, G. F.; Cancer Lett. 2013, 328, 207.

4. Gaul, C.; Njardarson, J. T.; Shan, D.; Dorn, D. C.; Wu, K. D.; Tong, W. P.; Huang, X. Y.; Moore, M. A.; Danishefsky, S. J.; J. Am. Chem. Soc. 2004, 126, 11326.

5. Ogasawara, M.; Matsubara, T.; Suzuki, H.; Biol. Pharm. Bull. 2001, 24, 917.

6. Lang, K.; Drell, T. L.; Zaenker, K. S.; Entschladen, F.; Recent Pat. Anti-Cancer Drug Disc. 2006, 1, 69.

7. Ogasawara, M.; Matsubara, T.; Suzuki, H.; Biol. Pharm. Bull. 2001, 24, 720 .

8. Koehn, F. E.; Carter, G. T.; Nat. Rev. Drug Disc. 2005, 4, 206.

9. Chin, Y. W.; Balunas, M. J.; Chai, H. B.; Kinghorn, A. D.; AAPS J. 2006, 8, E239.

10. Newman, D. J.; Cragg, G. M.; J. Nat. Prod. 2007, 70, 461.

11. Newman, D. J.; J. Med. Chem. 2008, 51, 2589.

12. Kinghorn, A. D.; Pan, L.; Fletcher, J. N.; Chai, H.; J. Nat. Prod. 2011, 74, 1539.

13. Newman, D. J.; Cragg, V.; J. Nat. Prod. 2012, 75, 311.

14. De Luca, V.; Salim, V.; Atsumi, S. M.; Yu, F.; Science 2012, 336, 1658.

15. Valli, M.; Dos Santos, R. N.; Figueira, L. D.; Nakajima, C. H.; Castro-Gamboa, I.; Andricopulo, A. D.; Bolzani, V. S.; J. Nat. Prod. 2013, 76, 439; http://nubbe.iq.unesp.br/portal/nubbedb. html, accessed in November 2016.

16. da Silva, R.; Navickiene, H. M.; Kato, M. J.; Bolzani, V. S.; Méda, C. I.; Young, M. C.; Furlan, M.; Phytochemistry 2002, $59,521$.

17. Navickiene, H. M.; Alécio, A. C.; Kato, M. J.; Bolzani, V. D.; Young, M. C.; Cavalheiro, A. J.; Furlan, M.; Phytochemistry 2000, 55, 621 .

18. Bezerra, D. P.; Castro, F. O.; Alves, A. P.; Pessoa, C.; Moraes, M. O.; . Silveira, E. R; Lima, M. A. S.; Elmiro, F. J. M.; CostaLotufo, L. V.; Braz. J. Med. Biol. Res. 2006, 39, 801.

19. Bezerra, D. P.; Militão, G. C.; De Castro, F. O.; Pessoa, C.; De Moraes, M. O.; Silveira, E. R.; Lima, M. A.; Elmiro, F. J.; Costa-Lotufo, L. V.; Toxicol. In Vitro 2007, 21, 1.

20. Cotinguiba, F.; Regasini, L. O.; Bolzani, V. S.; Debonsi, H. M.; Passerini, G. D.; Cicarelli, R. M. B.; Kato, M. J.; Furlan, M.; Med. Chem. Res. 2009, 8, 703.

21. Bezerra, D. P.; Pessoa, C.; De Moraes, M. O.; Saker-Neto, N.; Silveira, E. R.; Costa-Lotufo, L. V.; Eur. J. Pharm. Sci. 2013, $48,453$.

22. Raj, L.; Ide, T.; Gurkar, A. U.; Foley, M.; Schenone, M.; Li, X.; Tolliday, N. J.; Golub, T. R.; Carr, S. A.; Shamji, A. F.; Stern, A. M.; Mandinova, A.; Schreiber, S. L.; Lee, S. W.; Nature 2011, $475,231$.

23. Lee, S. W.; Mandinova, A.; WO pat. 2009/114126 A1, 2009.

24. Barcelos, R. C.; Pastre, J. C.; Vendramini-Costa, D. B.; Caixeta, V.; Longato, G. B.; Monteiro, P. A.; de Carvalho, J. E.; Pilli, R. A.; ChemMedChem 2014, 9, 2725.
25. Jarvius, M.; Fryknäs, M.; D’arcy, P.; Sun, C.; Rickardson, L.; Gullbo, J.; Haglund, C.; Nygren, P.; Linder, S.; Larsson, R.; Biochem. Biophys. Res. Commun. 2013, 431, 117.

26. Golovine, K. V.; Makhov, P. B.; Teper, E.; Kutikov, A.; Canter, D.; Uzzo, R. G.; Kolenko, V. M.; Prostate 2013, 73, 23.

27. Liu, Q. R.; Liu, J. M.; Chen, Y.; Xie, X. Q.; Xiong, X. X.; Qiu, X. Y.; Pan, F.; Liu, D.; Yu, S. B.; Chen, X. Q.; Oxidative Med. Cell. Longevity 2014, 2014, 653732.

28. Albini, A.; Iwamoto, Y.; Kleinman, H. K.; Martin, G. R.; Aaronson, S. A.; Kozlowski, J. M.; Mcewan, R. N.; Cancer Res. 1987, 47, 3239.

29. Yue, P. Y.; Leung, E. P.; Mak, N. K.; Wong, R. N.; J. Biomol. Screen. 2010, 15, 427.

30. Shan, D.; Chen, L.; Njardarson, J. T.; Gaul, C.; Ma, X.; Danishefsky, S. J.; Huang, X. Y.; Proc. Natl Acad. Sci. U. S. A. 2005, 102, 3772.

31. Barltrop, J. A.; Owen, T. C.; Cory, A. H.; Cory, J. G.; Bioorg. Med. Chem. Lett. 1991, 1, 611.

32. Adams, D. J.; Dai, M.; Pellegrino, G.; Wagner, B. K.; Stern, A. M.; Shamji, A. F.; Schreiber, S. L.; Proc. Natl Acad. Sci. U. S. A. 2012, 109, 15115.

33. Kemnitzer, W.; Drewe, J.; Jiang, S.; Zhang, H.; Wang, Y.; Zhao, J.; Jia, S.; Herich, J.; Labreque, D.; Storer, R.; Meerovitch, K.; Bouffard, D.; Rej, R.; Denis, R.; Blais, C.; Lamothe, S.; Attardo, G.; Gourdeau, H.; Tseng, B.; Kasibhatla, S.; Cai, S. X.; J. Med. Chem. 2004, 47, 6299.

34. Chatterjee, A.; Dutta, C. P.; Tetrahedron 1967, 23, 1769.

35. Boll, P. M.; Hansen, J.; Simonsen, O.; Thorup, N.; Tetrahedron 1984, 40, 171.

36. Rao, V. R.; Muthenna, P.; Shankaraiah, G.; Akileshwari, C.; Babu, K. H.; Suresh, G.; Babu, K. S.; Kumar, R. S.; Prasad, K. R.; Yadav, P. A.; Petrash, J. M.; Reddy, G. B.; Rao, J. M.; Eur. J. Med. Chem. 2012, 57, 344.

37. Boskovic, Z. V.; Hussain, M. M.; Adams, D. J.; Dai, M.; Schreiber, S. L.; Tetrahedron 2013, 69, 7559.

38. Pasquier, E.; Kavallaris, M.; IUBMB Life 2008, 60, 165.

39. Conde, C.; Cáceres, A.; Nat. Rev. Neurosci. 2009, 10, 319.

40. Desai, A.; Mitchison, T. J.; Annu. Rev. Cell Dev. Biol. 1997, 13, 83.

41. Vale, R. D.; Cell 2003, 112, 467.

42. Mitchison, T.; Kirschner, M.; Nature 1984, 312, 237.

43. Jordan, M. A.; Wilson, L.; Nat. Rev. Cancer 2004, 4, 253.

44. Lodish, H.; Berk, A.; Kaiser, C. A.; Krieger, M.; Scott, M.; Bretscher, A.; Ploegh, H.; Matsudaira, P.; Molecular Cell Biology, $6^{\text {th }}$ ed.; W. H. Freeman: New York, 2007.

45. Cassimeris, L.; Cell Motil. Cytoskeleton 1993, 26, 275.

46. Punganuru, S. R.; Madala, H. R.; Venugopal, S. N.; Samala, R.; Mikelis, C.; Srivenugopal, K. S.; Eur. J. Med. Chem. 2016, 107, 233.

47. Rayburn, E. R.; Ezell, S. J.; Zhang, R.; Mol. Cell. Pharmacol. 2009, 1, 29. 
48. Eiró, N.; Vizoso, F. J.; World J. Gastrointest. Surg. 2012, 4, 62.

49. Cytoskeleton. Kits \& Assays; available at http://www. cytoskeleton.com/kits, accessed in November 2016.

50. Bonne, D.; Heuséle, C.; Simon, C.; Pantaloni, D.; J. Biol. Chem. 1985, 260, 2819.

51. Dyrager, C.; Wickström, M.; Fridén-Saxin, M.; Friberg, A.; Dahlén, K.; Wallén, E. A.; Gullbo, J.; Grøtli, M.; Luthman, K.; Bioorg. Med. Chem. 2011, 19, 2659.
52. Ruan, B. F.; Lu, X.; Tang, J. F.; Wei, Y.; Wang, X. L.; Zhang, Y. B.; Wang, L. S.; Zhu, H. L.; Bioorg. Med. Chem. 2011, 19, 2688.

53. Perrin, D. D.; Armarego, W. L. F.; Purification of Laboratory Chemicals, 3rd ed.; Pergamon Press: Oxford, 1988.

54. Seo, Y. H.; Kim, J. K.; Jun, J. G.; Bioorg. Med. Chem. Lett. 2014, 24, 5727. 